iron age, which, with its characteristic Celtic ornament combining the use of metal and enamel, has long been one of the Museum's most striking exhibits among British antiquities. The decoration of the seabbard mount is an example of the earliest Celtic art of Britain, and shows the La Tène curvilinear style of ornamentation in the form in which it reached Britain. Other accessions, also of great interest, come from a round barrow at Riffley Wood, near King's Lynn, which has been exeavated by Mr. I. J. Thatcher and Mr. P. L. K. Sebwabe. Among these are a segmented bead and a ring pendant of bluish-green faience, which were associated with nine or ten cremated urn burials of the Middle Bronze Age found on top of the mound. They belong to a class of ornament which has been found in bronze age burials in Britain and on the Continent ; and they agree in all respects with examples found at Tell el-Amama in Egypt, dating from about 1400 B.c. The grave pit of the mound below the level at which the urn burials were found, contained no remains; but the whole of the surface-level below the barrow was covered with pottery fragments, representing hundreds of vessels. These sherds were of beaker pottery of the Early Bronze Age, of the approximate dating of 1800 B.c. It seems clear that this was not a habitation site, and the sherds are thought to be either the debris of the floor of the dead man's hut, which was brought here entire, or, perhaps more probably, the result of a ritual, which involved the scattering of a large number of potsherds.

\section{The Iron Industry in South Yorkshire}

BEFORE the introduction of mild steel about sixty years ago, engineers had to rely on wrought iron made by the puddling process introduced by Henry Cort in 1783. Among the various brands of wrought iron none was superior to those made in Yorkshire. But long before Cort's time iron was made in Yorkshire, and in a paper entitled "The South Yorkshire Iron Industry 1698-1759", read to the Newcomen Society on December 14, Dr. A. Raistrick gave an account of the operations carried out in the SheffieldLeeds-Huddersfield area about two hundred years ago. The source of his information was manuscripts discovered a few years ago, and now preserved by the Bradford City Museums and Library Committee, relating to the activities of the various branches of the Spencer family, all Quakers. The documents give accounts of 10 furmaces, 14 forges and 5 slitting mills, and though much of the information relates to the business side of the industry, they embody a considerable amount of technical information about the mining of the iron ore, the construction and working of the furnaces and forges and the production of charcoal. The main group of furnaces was on the outcrop of the Tankersley Ironstone and near streams which were used for driving water-wheels for working the bellows. As in Sussex, a determining factor of the industry was the supply of charcoal, and it was rarely possible for a furnace to be worked for more than half the year. The manuscripts, as Dr. Raistrick said, put a new complexion on the story of the iron industry in the area.

\section{British Coal Utilisation Research Association}

ON December 14, the British Coal Utilisation Research Association held its first ordinary general meeting under the presidency of Sir Evan Williams. It was founded in April last, having incorporated the Research Department of the Combustion Appliance Makers Association (Solid Fuel) and with a membership covering all sections of the industries of coal and its appliance manufacturers. Its income from these sources and Government grant is guaranteed at $£ 29,000$ for five years. Premises near West Brompton Station have been secured and are being adapted to the purposes of an experimental station. It was stated that fruitful work has already been done in both the domestic and the industrial sections. In the former this has been concerned with the open fire, and the use of natural smokeless fuels and smoke reduction. In this connexion it is claimed that success has been achieved in the design of solid fuel cookers to replace in railway restaurant cars those fired with oil gas. On the industrial side, the supply and use of solid fuel for small industry, pulverized fuel, and industrial temperature measurement have engaged attention. A special committee has been set up to study the question of producer gas transport and supplement the work already in progress at the Fuel Research Station. It has long been a matter of reproach against the coal industry that it has shown complete indifference to the rational and efficient utilization of its commercial product. The launching of this Association will remove this reproach, and, as the president said, it will be "the missing member of a team which will work in harmony to bring about a more perfect knowledge of the properties of coal measures and advances in their fuller and better utilization".

\section{Blind Landing System for Royal Air Force Equipment}

THE Air Ministry has announced its intention to equip all R.A.F. bombers and reconnaissance aircraft with the Lorenz blind approach system. If experiments during this winter prove this to be successful, the fighter class of aircraft will then also be so equipped. This follows the announcement that forty R.A.F. aerodromes would have the radio transmitting apparatus for this system installed, as mentioned in NATURE of November 26. The apparatus to be carried in each machine weighs $50 \mathrm{lb}$. and costs about $£ 200$. Its manipulation demands a certain technique, and pilots need considerable practice before being able to use it in addition to the other movements and observations that are incidental to the operation of landing a modern high-speed aeroplane. A special 'Link' trainer is used for practice in the use of the Lorenz system, upon which approaches and landings can be simulated without leaving the ground. These are to be provided at R.A.F. flying schools, in addition to which each service station will carry one. The training of the personnel will be undertaken by special instructors, who will have already attended courses at the Central Flying School at Upavon, Wilts. 